\title{
Pengaruh Formulasi Jamur Tiram Putih (Pleurotus oestreatus) dan Tapioka Terhadap Sifat Fisik, Organoleptik, dan Kimia Kerupuk
}

\section{The Influence of White Oyster Mushroom (Pleurotus oestreatus) Formulation and Tapioca to Physical, Organoleptic, and Chemical Characteristics of Cracker}

\author{
Sussi Astuti ${ }^{1)}$, Suharyono A.S. ${ }^{1)}$, dan Nopena Fitra ${ }^{2)}$ \\ ${ }^{1}$ Dosen Jurusan Teknologi Hasil Pertanian Fakultas Pertanian Universitas Lampung \\ ${ }^{2}$ Alumni Jurusan Teknologi Hasil Pertanian Fakultas Pertanian Universitas Lampung \\ Jl. Prof. Soemantri Brodjonegoro No.1 Bandar Lampung 35145 \\ e-mail : sussi_astuti@yahoo.com
}

\begin{abstract}
White oyster (Pleurotus oestreatus) mushroom has high nutrition content. The white oyster mushroom processing to be cracker product is one of product diversification efforts from mushroom. This research was conducted to find out the best formulation of tapioca and oyster mushroom to produce the best characteristics of oyster mushroom crackers. These characteristics include expansion volume, sensory, and chemist. This research was designed in a Completely Randomized Block Design with 3 replication. The treatments had 7 formulation levels of tapioca and oyster mushroom flour, that were N1 (0\%:100\%), N2 (10\%: 90\%), N3 (20\%: 80\%), N4 (30\%: 70\%), N5 (40\%:60\%), N6 (50\%: 50\%), and N7 (60\%: 40\%), respectively. Data were analiyzed with analysis of varians to find out the treatment effects, then the data were further analyzed with Honestly Significant Difference (HSD) test on level of 5\% to find the best formulation. The results showed that formulation N2 (10\% white oyster mushroom and 90\% tapioca) was the best formulation with expansion volume of 452,28\%, crunchy texture, rather-typical of oyster mushroom taste, rather-typical of oyster mushroom aroma, water content of 7,20\% (\%db), ash content of 1,03\% (\%db), fat content of $0,46 \%(\% d b)$, protein content of $1,66 \%(\% d b)$, and fibre content of $0,24 \%(\% d b)$. However, the protein content didn't include the qualification of cracker standard quality (SNI 01-2713-1999).
\end{abstract}

Keywords : white oyster mushroom, tapioca, cracker

Diterima :30 Juni 2016, disetujui 30 Agustus 2016

\section{PENDAHULUAN}

Jamur tiram (Pleurotus oestreatus) merupakan jamur konsumsi dari jenis jamur kayu dengan kandungan nutrisi yang lebih lengkap dibanding komoditas sayuran lain (Martawijaya dan Nurjayadi, 2010). Menurut Patel et al. (2012), jamur tiram mengandung protein, vitamin, mineral dan serat yang tinggi. Bernas et al. 2(006) menyatakan bahwa jamur tiram dapat dimanfaatkan sebagai flavor enhancher dengan kadar asam glutamat sebesar $17,7 \mathrm{~g} / 100 \mathrm{~g}$ prot. Jamur tiram memiliki kandungan protein dan karbohidrat lebih tinggi dibanding daging sapi namun kadar lemak lebih rendah, sehingga jamur tiram dapat dimanfaatkan sebagai sumber gizi bagi orang yang melakukan diet. 
Jamur tiram termasuk bahan pangan yang mudah rusak. Beberapa hari setelah panen, mutu jamur tiram turun dengan cepat sampai tidak layak dimakan. Perubahan mutu yang terjadi antara lain layu, warna menjadi kecoklatan, lunak dan cita rasanya berubah. Pengolahan bahan pangan merupakan salah satu fungsi untuk memperbaiki mutu bahan pangan, memberikan kemudahan dalam penanganan, efisiensi biaya produksi, memperbaiki cita rasa dan aroma dan penganekaragaman produk. Pengolahan jamur tiram menjadi produk kerupuk merupakan salah satu upaya diversifikasi produk olahan jamur. Kerupuk oleh sebagian masyarakat Indonesia dikenal sebagai makanan ringan dan praktis tidak memerlukan metode penyimpanan khusus dalam distribusi.

Tapioka merupakan jenis tepung yang banyak digunakan sebagai bahan baku kerupuk yang berperan dalam pembentukan tekstur dan pembentukan adonan. Tapioka memiliki daya ikat yang tinggi dan membentuk struktur yang kuat dibanding tepung jagung, kentang, dan gandum atau terigu (Kusnandar, 2010). Tapioka mengandung pati yang hampir seluruhnya bersifat lunak dan membentuk pasta, sehingga cocok digunakan dalam pembuatan berbagai macam produk olahan pangan (Winarno, 2004). Kerupuk tapioka mengandung protein rendah karena tapioka memiliki kandungan protein rendah, sedangkan kerupuk udang, kerupuk ikan, kerupuk susu dan kerupuk kedelai merupakan kerupuk dengan kandungan protein tinggi. Jamur tiram dapat dimanfaatkan dalam pembuatan kerupuk karena kandungan protein sebesar 27\% dan karbohidrat sebesar 58\%, dengan aroma dan rasa yang khas (Patel et al., 2012). Ketersediaan bahan baku memungkinkan pemanfaatan jamur tiram untuk dibuat kerupuk sehingga meningkatkan nilai jual jamur tiram.

Sejauh ini, belum diketahui formulasi jamur tiram dan tapioka yang tepat dalam pembuatan kerupuk jamur tiram. Menurut Martawijaya dan Nurjayadi (2010) kerupuk jamur tiram dengan formulasi 50\% jamur tiram : 50\% tapioka menghasilkan rasa kerupuk jamur tiram yang disukai, namun belum ada informasi sifat fisik dan kimia kerupuk formulasi tersebut. Penelitian ini dilakukan untuk mendapatkan formulasi yang tepat antara jamur tiram dan tapioka sehingga kerupuk jamur tiram yang dihasilkan memenuhi standar mutu kerupuk (SNI 01-2713-1999).

\section{METODE}

Bahan utama adalah tapioka merk Tani dan jamur tiram (Pleurotus Oestreatus) dari salah satu petani jamur tiram di Langkapura Bandar Lampung. Bahan tambahan adalah telur bebek, air, gula pasir, garam, minyak goreng, tali/benang dan plastik polipropilen (PP), sedang bahan-bahan kimia antara lain aquadest, larutan $\mathrm{H} 2 \mathrm{SO} 4$ pekat, $\mathrm{H} 2 \mathrm{SO} 4$ 1,25\%, $\mathrm{NaOH} 1,25 \%, \mathrm{HCl} \mathrm{0,02} \mathrm{N}, \mathrm{NaOH} 50 \%, \mathrm{H} 2 \mathrm{BO}$, Na2S2O3, K2SO4, $\mathrm{HgO}$ dan alkohol. Alat untuk pembuatan kerupuk yaitu baskom, timbangan, panci pengukus, blender, freezer, plastik, talenan, pisau, slicer, pengaduk, loyang dan alat penggorengan, sedangkan peralatan untuk analisis yaitu mikrometer sekrup, kertas saring, cawan porselin, oven, desikator, labu Kjeldahl, alat ekstraksi Soxhlet, tanur listrik, dan alat-alat gelas.

Perlakuan disusun secara tunggal dalam Rancangan Acak Kelompok Lengkap (RAKL) dengan 3 ulangan. Perlakuan formulasi jamur tiram dan tapioka sebanyak 7 taraf, yaitu N1 (0\%:100\%); N2 (10\%: 90\%); N3 (20\%: 80\%); N4 (30\%: 70\%); N5 (40\%: 60\%); N6 (50\%: 50\%) dan N7 (60\%: 40\%). Data dianalisis sidik ragam untuk mendapatkan penduga ragam galat dan uji signifikansi untuk mengetahui pengaruh perlakuan. Apabila terdapat pengaruh yang nyata, data dianalisis lebih lanjut menggunakan uji Beda Nyata Jujur (BNJ) pada taraf 5\%.

Pembuatan bubur jamur tiram diawali dengan mencuci dan meniriskan jamur tiram, lalu dihaluskan dengan blender selama 5 menit. Tahapan pembuatan kerupuk jamur tiram sebagai berikut: Pada setiap satuan percobaan dibuat perbandingan bahan baku dengan total berat $500 \mathrm{~g}$. Untuk formulasi N3 (20\% jamur tiram : $80 \%$ tapioka), sebanyak $100 \mathrm{~g}$ bubur jamur tiram dicampur $400 \mathrm{~g}$ tapioka, diaduk sampai rata lalu ditambah 
bumbu halus yang terdiri dari garam dapur $10 \mathrm{~g}$, gula pasir $10 \mathrm{~g}$, bawang putih $10 \mathrm{~g}$, telur bebek $80 \mathrm{~g}$, dan penambahan air panas $\pm 100 \mathrm{ml}$. Setelah itu adonan dicampur sampai kalis, dibentuk gulungan/dodolan yang dikemas dalam plastik PP dengan diameter $3 \mathrm{~cm}$ dan panjang $15 \mathrm{~cm}$, diikat dengan tali/benang dan dipanaskan pada suhu $80^{\circ} \mathrm{C}$ selama 45 menit. Selama pemanasan, suhu dijaga stabil selama 45 menit menggunakan termometer dengan mengatur besar kecil api. Selanjutnya dodolan adonan didinginkan dan disimpan pada suhu 4-8oC selama 12 jam, dipotong tipis dengan ketebalan $\pm 2-3 \mathrm{~mm}$ menggunakan slicer, selanjutnya dikeringkan dengan oven pada suhu $\pm 60^{\circ} \mathrm{C}$ selama 10 jam, sampai kadar air kerupuk mentah \pm $11 \%$.

Pengamatan terhadap kerupuk jamur tiram matang meliputi volume pengembangan (Zulviani, 2000) dan uji organoleptik (tekstur, rasa, warna dan aroma). Kerupuk matang diperoleh melalui penggorengn deep frying pada suhu $160-180^{\circ} \mathrm{C}$ selama 10 detik. Uji kimia (kadar air, kadar abu, kadar lemak, kadar protein, dan kadar serat kasar) (AOAC, 1995) dilakukan terhadap kerupuk jamur tiram mentah.

\section{HASIL DAN PEMBAHASAN}

Volume pengembangan. Hasil analisis sidik ragam menunjukkan bahwa formulasi jamur tiram dan tapioka berpengaruh sangat nyata terhadap volume pengembangan kerupuk matang yang dihasilkan (tabel 1).

Tabel 1. Hasil uji lanjut BNJ terhadap volume pengembangan kerupuk

\begin{tabular}{ll}
\hline \multicolumn{1}{c}{ Perlakuan } & Nilai tengah \\
\hline N2 (10\% jamur tiram dan 90\% tapioka) & $452,29 \mathrm{a}$ \\
N4 (30\% jamur tiram dan 70\% tapioka) & $415,54 \mathrm{ab}$ \\
N1 (100\% tapioka) & $330,78 \mathrm{abc}$ \\
N3 (20\% jamur tiram dan 80\% tapioka) & $328,53 \mathrm{abc}$ \\
N7 (60\% jamur tiram dan 40\% tapioka) & $292,62 \mathrm{abc}$ \\
N5 (40\% jamur tiram dan 60\% tapioka) & $247,95 \mathrm{bc}$ \\
N6 (50\% jamur tiram dan 50\% tapioka) & $205,57 \mathrm{c}$ \\
\hline BNJ 0,05 =167,808 & \\
\hline
\end{tabular}

Ket : Angka yang diikuti oleh huruf yang berbeda pada kolom yang sama menunjukkan adanya perbedaan nyata $(\mathrm{p}<0.05)$

Berdasarkan Tabel 1, formulasi kerupuk jamur tiram dengan proporsi jamur tiram yang semakin banyak mengakibatkan volume pengembangan kerupuk jamur yang cenderung menurun. Penurunan volume pengembangan kerupuk jamur tiram dipengaruhi oleh kadar protein dan kadar serat kasar pada jamur tiram. Tingginya kandungan protein pada jamur tiram menyebabkan penurunan volume pengembangan kerupuk karena protein terikat sebagai matriks dengan butiran pati dan menghambat proses gelatinisasi. Hal ini didukung Chinachoti et al. (1990) yang menyatakan bahwa penambahan bahan selain pati yang mengikat air dapat menyulitkan proses pemasakan pati. Haryadi et al. (1994) menyatakan bahwa semakin banyak penambahan bahan bukan pati, makin kecil pengembangan kerupuk pada saat penggorengan. Dilaporkan lebih lanjut bahwa semakin banyak komponen protein yang membentuk kompleks dengan butiran pati, maka kemampuan amilopektin dalam pengembangan kerupuk menjadi berkurang pada saat produk kerupuk digoreng. Menurut Tester dan Morrison (1990), pengembangan volume diduga dipengaruhi oleh amilopektin, karena partikel-partikel di dalam molekul amilopektin menentukan permulaan dari proses pengembangan dan gelatinisasi. Semakin tinggi kandungan amilopektin, rasio pengembangan kerupuk makin besar karena amilopektin memiliki daya pengembangan yang lebih tinggi dibanding amilosa. Muchtadi et al. (1988) menyatakan bahwa perbandingan kandungan amilosa dan amilopektin dalam pati 


\section{Jurnal Penelitian Pertanian Terapan}

berpengaruh terhadap kerenyahan suatu produk. Kandungan amilopektin yang tinggi membuat produk menjadi mudah mengembang, sedangkan produk dengan kandungan amilosa tinggi lebih rapat, lebih keras, dan kurang mengembang. Menurut Lu et al., (1996), granula pati dan ketersediaan air merupakan faktor yang menentukan pengembangan volume, namun amilosa hanya memiliki sedikit efek terhadap pengembangan volume.

Kerupuk yang seluruh komponennya pati menghasilkan volume pengembangan tertinggi. Hal ini karena proses gelatinisasi tidak terganggu atau dihambat oleh komponen lain seperti serat kasar (Muryati, 1996). Hasil penelitian pada Tabel 10 menunjukkan bahwa semakin tinggi penambahan jamur tiram dalam formulasi kerupuk jamur, kandungan serat kasar kerupuk jamur tiram semakin meningkat. Muryati (1996) menyatakan bahwa serat kasar dalam adonan kerupuk berpengaruh terhadap daya kembang kerupuk karena serat kasar tidak larut dalam air sehingga mengurangi penyerapan air oleh amilum.

Tekstur. Hasil analisis ragam menunjukkan bahwa formulasi jamur tiram dan tapioka berpengaruh sangat nyata terhadap tekstur kerupuk matang yang dihasilkan (tabel 2).

Tabel 2. Hasil uji lanjut BNJ terhadap tekstur kerupuk

\begin{tabular}{lcc}
\hline Perlakuan & Nilai tengah & Keterangan \\
\hline N5 (40\% jamur tiram dan 60\% tapioka) & $3,93 \mathrm{a}$ & Renyah \\
N6 (50\% jamur tiram dan 50\% tapioka) & $3,87 \mathrm{a}$ & Renyah \\
N4 (30\% jamur tiram dan 70\% tapioka) & $3,73 \mathrm{a}$ & Renyah \\
N7 (60\% jamur tiram dan 40\% tapioka) & $3,60 \mathrm{a}$ & Renyah \\
N1 (100\% tapioka) & $3,45 \mathrm{~b}$ & Agak renyah \\
N2 (10\% jamur tiram dan 90\% tapioka) & $3,45 \mathrm{~b}$ & Agak renyah \\
N3 (20\% jamur tiram dan 80\% tapioka) & $3,43 \mathrm{~b}$ & Agak renyah \\
\hline
\end{tabular}

BNJ $0,05=0,782$

Ket : Angka yang diikuti oleh huruf yang berbeda pada kolom yang sama menunjukkan adanya perbedaan nyata $(\mathrm{p}<0.05)$

Berdasarkan Tabel 2, tekstur kerupuk jamur tiram yang disukai yaitu renyah (skor 4), sedangkan teksturyang agak disukai yaitu agak renyah (skor 3). Kerupuk pada formulasi N1 (100\% tapioka), N2 (10\% jamur tiram dan 90\% tapioka) dan N3 (20\% jamur tiram dan $80 \%$ tapioka) menghasilkan tekstur kerupuk agak renyah. Hal ini diduga karena kerupuk tersebut memiliki kadar air paling tinggi yaitu 6,74-7,53\% (Tabel 6). Menurut Muchtadi et al.(1988), kandungan air yang tinggi dalam bahan akan menghambat proses pengembangan produk, sehingga tekstur yang dihasilkan menjadi kurang kering dan kurang renyah. Kandungan pati yang tinggi dalam pembuatan kerupuk menyebabkan terjadinya proses gelatinisasi. Pati yang tergelatinisasi sempurna akan menghasilkan pemecahan sel pati yang lebih besar selama penggorengan. Produk yang mengembang akan menghasilkan produk yang renyah dan memiliki kadar air yang rendah. Perbedaan tekstur antar perlakuan disebabkan perbedaan perbandingan jamur tiram dengan tapioka yang ditambahkan.

Rasa. Hasil analisis ragam menunjukkan bahwa formulasi jamur tiram dan tapioka berpengaruh sangat nyata terhadap rasa kerupuk (tabel 3).

Berdasarkan Tabel 3, komposisi jamur tiram yang semakin tinggi dan tapioka rendah meningkatkan kesukaan panelis terhadap rasa kerupuk campuran jamur tiram dan tapioka. Meningkatnya kesukaan panelis terhadap rasa kerupuk jamur disebabkan bertambahnya komposisi jamur tiram putih dalam adonan kerupuk sehingga mengakibatkan rasa kerupuk menjadi lebih khas jamur. Bernas et al. (2006) menyatakan bahwa total asam amino jamur tiram terdapat dalam jumlah lengkap sebesar $46 \mathrm{~g} / 100 \mathrm{~g}$ protein, mendekati total asam amino telur ayam sebesar $47,1 \mathrm{~g} / 100 \mathrm{~g}$ protein sehingga kualitas protein jamur tiram mendekati protein telur. Dilaporkan bahwa kadar asam glutamat yang terkandung dalam jamur tiram sebesar 17,7 g/100g protein. Asam glutamat jamur tiram memberikan rasa gurih dan meningkatkan cita rasa umami kerupuk jamur tiram. 
Astuti, S dkk: Pengaruh Formulasi Jamur Tiram Putih (Pleurotus Oestreatus) dan Tapioka...

Tabel 3. Hasil uji lanjut BNJ terhadap rasa kerupuk

\begin{tabular}{lcl}
\hline \multicolumn{1}{c}{ Perlakuan } & Nilai tengah & Keterangan \\
\hline N6 (50\% jamur tiram dan 50\% tapioka) & $3,20 \mathrm{a}$ & Agak khas jamur \\
N5 (40\% jamur tiram dan 60\% tapioka) & $2,87 \mathrm{~b}$ & Agak khas jamur \\
N7 (60\% jamur tiram dan 40\% tapioka) & $2,87 \mathrm{~b}$ & Agak khas jamur \\
N4 (30\% jamur tiram dan 70\% tapioka) & $2,77 \mathrm{~b}$ & Agak khas jamur \\
N3 (20\% jamur tiram dan 80\% tapioka) & $2,77 \mathrm{~b}$ & Agak khas jamur \\
N2 (10\% jamur tiram dan 90\% tapioka) & $2,47 \mathrm{c}$ & Tidak khas jamur \\
N1 (100\% tapioka) & $2,45 \mathrm{c}$ & Tidak khas jamur \\
\hline BNJ $0,05=0,279$ & &
\end{tabular}

Ket : Angka yang diikuti oleh huruf yang berbeda pada kolom yang sama menunjukkan adanya perbedaan nyata $(\mathrm{p}<0.05)$

Warna. Hasil analisis ragam menunjukkan bahwa formulasi jamur tiram dan tapioka berpengaruh sangat nyata terhadap warna kerupuk matang yang dihasilkan.

Tabel 4. Hasil uji lanjut BNJ terhadap warna kerupuk

\begin{tabular}{lcc}
\hline \multicolumn{1}{c}{ Perlakuan } & Nilai tengah & Keterangan \\
\hline N1 (100\% tapioka) & $4,47 \mathrm{a}$ & Putih \\
N2 (10\% jamur tiram dan 90\% tapioka) & $4,08 \mathrm{ab}$ & Putih kekuningan \\
N3 (20\% jamur tiram dan 80\% tapioka) & $3,48 \mathrm{bc}$ & Putih kekuningan \\
N4 (30\% jamur tiram dan 70\% tapioka) & $3,18 \mathrm{~cd}$ & Putih kecoklatan \\
N5 (40\% jamur tiram dan 60\% tapioka) & $2,88 \mathrm{~cd}$ & Putih kecoklatan \\
N6 (50\% jamur tiram dan 50\% tapioka) & $2,53 \mathrm{~d}$ & Coklat \\
N7 (60\% jamur tiram dan 40\% tapioka) & $2,47 \mathrm{~d}$ & Coklat \\
\hline BNJ 0,05 =0,870
\end{tabular}

Ket : Angka yang diikuti oleh huruf yang berbeda pada kolom yang sama menunjukkan adanya perbedaan nyata $(\mathrm{p}<0.05)$

Berdasarkan Tabel 4, komposisi jamur tiram yang tinggi dan tapioka yang rendah dalam proses pembuatan kerupuk jamur tiram akan menurunkan tingkat kesukaan panelis terhadap warna kerupuk yang dihasilkan. Hal ini karena tingginya komposisi jamur tiram menyebabkan warna kerupuk jamur tiram yang dihasilkan semakin coklat. Sebaliknya komposisi tapioka yang tinggi menyebabkan warna kerupuk semakin putih.

Hasil ini sejalan dengan pendapat Ridwan et al. (1994) yang menyatakan bahwa semakin tinggi bahan non pati ditambahkan ke dalam adonan, maka akan menurunkan skor warna kerupuk yang dihasilkan karena warnanya semakin mendekati coklat. Semakin tinggi penambahan komposisi bahan yang mengandung protein ke dalam adonan, tingkat kesukaan panelis terhadap warna kerupuk yang dihasilkan semakin menurun (Rahardjo dan Haryadi, 1997; Astawan dan Christina, 1998).

Warna coklat pada kerupuk formulasi jamur tiram dengan tapioka disebabkan oleh reaksi pencoklatan (Maillard), yang terjadi pada saat perlakuan pemanasan adonan, pengeringan dalam oven dan penggorengan deep frying. Menurut Kusnandar (2010), reaksi antara gugus amino dari protein dengan suatu aldosa atau ketosa membentuk senyawa basa schiff, kemudian terjadi perubahan menurut reaksi Amadori menjadi amino ketosa. Degradasi reaksi Amadori membentuk turunan furfuraldehid menghasilkan reaksi antara metil $\alpha$ dikarbonil dan $\alpha$-dikarboksil.Polimerisasi senyawa aldehid membentuk senyawa coklat disebut melanoidin.Hasil reaksi tersebut menghasilkan bahan berwarna coklat yang sering dikehendaki atau menjadi pertanda penurunan mutu.Dalam pembuatan kerupuk, reaksi pencoklatan merupakan reaksi yang tidak dikehendaki. 
Aroma. Hasil analisis menunjukkan bahwa formulasi jamur tiram dan tapioka berpengaruh sangat nyata terhadap aroma kerupuk.

Tabel 5. Hasil uji lanjut BNJ terhadap aroma kerupuk

\begin{tabular}{lll}
\hline \multicolumn{1}{c}{ Perlakuan } & Nilai tengah & \multicolumn{1}{c}{ Keterangan } \\
\hline N6 (50\% jamur tiram dan 50\% tapioka) & $2,93 \mathrm{a}$ & Agak khas jamur \\
N7 (60\% jamur tiram dan 40\% tapioka) & $2,85 \mathrm{a}$ & Agak khas jamur \\
N5 (40\% jamur tiram dan 60\% tapioka) & $2,78 \mathrm{ab}$ Agak khas jamur \\
N4 (30\% jamur tiram dan 70\% tapioka) & $2,70 \mathrm{ab}$ & Agak khas jamur \\
N3 (20\% jamur tiram dan 80\% tapioka) & $2,68 \mathrm{ab}$ & Agak khas jamur \\
N2 (10\% jamur tiram dan 90\% tapioka) & $2,53 \mathrm{~b}$ & Agak khas jamur \\
N1 (100\% tapioka) & $2,23 \mathrm{c}$ & Tidak khas jamur \\
\hline BNJ 0,05 = 0,270 & &
\end{tabular}

Ket : Angka yang diikuti oleh huruf yang berbeda pada kolom yang sama menunjukkan adanya perbedaan nyata $(\mathrm{p}<0.05)$

Kesukaan panelis terhadap aroma kerupuk jamur tiram berkisar antara tidak khas jamur sampai agak khas jamur (skor 2-3) (Tabel 5). Tabel 5 menunjukkan bahwa komposisi jamur tiram yang tinggi dan tapioka yang rendah meningkatkan kesukaan panelis terhadap aroma kerupuk matang yang dihasilkan yaitu khas jamur. Menurut Cahyana et al. (1999) timbulnya aroma pada kerupuk jamur tiram putih disebabkan oleh pemecahan asam-asam amino yang terdapat dalam jamur tiram putih yaitu lisin, metionin, triptofan, threonin, valin, leusin, isoleusin, histidin dan fenilalanin. Semakin rendah jamur tiram yang ditambahkan menurunkan tingkat kesukaan panelis terhadap aroma kerupuk jamur tiram yaitu tidak khas jamur. Hal ini disebabkan tingginya proporsi tapioka dibanding jamur tiram sehingga mengakibatkan berkurangnya aroma khas jamur tiram.

Kadar air. Hasil analisis sidik ragam menunjukkan bahwa formulasi jamur tiram dan tapioka berpengaruh sangat nyata terhadap kadar air kerupuk (Tabel 6).

Tabel 6. Hasil uji lanjut BNJ terhadap kadar air kerupuk (\%bk)

\begin{tabular}{lc}
\hline Perlakuan & Nilai tengah \\
\hline N1 (100\% tapioka) & $7,53 \mathrm{a}$ \\
N2 (10\% jamur tiram dan 90\% tapioka) & $7,20 \mathrm{~b}$ \\
N3 (20\% jamur tiram dan 80\% tapioka) & $6,74 \mathrm{c}$ \\
N4 (30\% jamur tiram dan 70\% tapioka) & $6,72 \mathrm{c}$ \\
N7 (60\% jamur tiram dan 40\% tapioka) & $6,36 \mathrm{~d}$ \\
N5 (40\% jamur tiram dan 60\% tapioka) & $6,31 \mathrm{~d}$ \\
N6 (50\% jamur tiram dan 50\% tapioka) & $6,23 \mathrm{~d}$ \\
\hline BNJ $0,05=0,167$ &
\end{tabular}

BNJ $0,05=0,167$

Ket : Angka yang diikuti oleh huruf yang berbeda pada kolom yang sama menunjukkan adanya perbedaan nyata $(\mathrm{p}<0.05)$

Berdasarkan Tabel 6, semakin banyak penambahan jamur tiram dalam pembuatan kerupuk akan menurunkan kadar air kerupuk jamur tiram yang dihasilkan. Winarno (1997) menyatakan bahwa pada saat terjadi proses gelatinisasi, molekul-molekul air akan masuk ke dalam butir-butir pati. Pada saat pemanasan, energi kinetik dari molekul-molekul air yang panas memecah ikatan hidrogen antar molekul-molekul pati. Ikatan hidrogen terbentuk ketika pati membentuk ikatan hidrogen dengan molekul air selain dengan pati yang lain. Saat ikatan hidrogen terbentuk, air dapat menembus lebih jauh ke dalam granula pati dan pembengkakan terjadi yang mengakibatkan membesarnya granula pati. Pembengkakan ini diikuti dengan terikatnya molekul air di dalam molekul pati. Menurut Muryati (1996), komponen selain pati yang ditambahkan ke dalam adonan akan mengganggu proses penyerapan air pada saat proses gelatinisasi. 
Astuti, S dkk : Pengaruh Formulasi Jamur Tiram Putih (Pleurotus Oestreatus) dan Tapioka...

Semakin banyak jumlah pati dalam kerupuk jamur tiram, maka kapasitas absorbsi air semakin besar. Pati tapioka mengandung 17\% amilosa dan 83\% amilopektin (Kusnandar, 2010). Semakin banyak penambahan jamur tiram dalam formulasi kerupuk, kadar amilosa semakin rendah. Kadar amilosa dalam bahan akan berpengaruh terhadap banyaknya molekul air dari lingkungannya, sehingga hanya sedikit sekali molekul air yang dapat ditangkap. Hal ini didukung oleh data hasil penelitian, adanya kecenderungan penurunan kadar air kerupuk dengan semakin rendahnya persentase tapioka dalam formulasi kerupuk.

Proses gelatinisasi sangat menentukan banyaknya air yang terserap ke dalam adonan sehingga juga akan menentukan kadar air produk akhir. Winarno (1997) menyatakan bahwa pada saat terjadi proses gelatinisasi, molekul-molekul air akan masuk ke dalam butir-butir pati. Molekul air ini akan terikat kuat secara kimia di dalam matriks. Ikatan ini terbentuk melalui ikatan hidrogen antara molekul air dengan molekul amilopektin pada tapioka. Pada saat ikatan hidrogen terbentuk, air akan menembus pati dan akan terikat ke dalam matriknya secara kimia.

Kadar air dari ketujuh formulasi kerupuk jamur tiram berada dalam kisaran 6-7\%. Sampai saat ini, belum ada penentuan persyaratan mutu untuk produk olahan kerupuk jamur tiram. Berdasarkan stándar mutu (SNI 01-2713-1999), kadar air kerupuk ikan maksimal 11\%. Hal ini menunjukkan bahwa kadar air kerupuk jamur tiram sudah memenuhi standar mutu SNI untuk jenis kerupuk.

Kadar abu. Hasil analisis sidik ragam menunjukkan bahwa formulasi jamur tiram dan tapioka berpengaruh sangat nyata terhadap kadar abu kerupuk (tabel 7).

Tabel 7. Hasil uji lanjut BNJ terhadap kadar abu kerupuk (\%bk)

\begin{tabular}{rc}
\hline Perlakuan & Nilai tengah \\
\hline N7 (60\% jamur tiram dan 40\% tapioka) & $2,78 \mathrm{a}$ \\
N6 (50\% jamur tiram dan 50\% tapioka) & $2,38 \mathrm{~b}$ \\
N5 (40\% jamur tiram dan 60\% tapioka) & $1,82 \mathrm{c}$ \\
N4 (30\% jamur tiram dan 70\% tapioka) & $1,49 \mathrm{~d}$ \\
N3 (20\% jamur tiram dan 80\% tapioka) & $1,22 \mathrm{e}$ \\
N2 (10\% jamur tiram dan 90\% tapioka) & 1,11 ef \\
N1 (100\% tapioka) & $0,93 \mathrm{f}$ \\
\hline
\end{tabular}

BNJ $0,05=0,230$

Ket : Angka yang diikuti oleh huruf yang berbeda pada kolom yang sama menunjukkan adanya perbedaan nyata $(\mathrm{p}<0.05)$

Berdasarkan Tabel 7, kadar abu kerupuk jamur tiram cenderung meningkat dengan semakin besarnya jumlah jamur tiram yang ditambahkan. Hal ini disebabkan jumlah proporsi jamur tiram yang lebih besar dibanding tapioka, sehingga sisa pembakaran bahan-bahan organik, seperti protein, lemak, karbohidrat dan sebagainya, yang terdapat dalam jamur tiram relatif lebih besar. Hal ini didukung oleh Suriawiria (2002) yang menyatakan bahwa kadar abu jamur tiram sebesar 9,3\%, lebih besar dibanding kadar abu tapioka sebesar 0,06\% (Wirakartakusumah et al., 1989).

Kadar lemak. Hasil analisis sidik ragam menunjukkan bahwa formulasi jamur tiram dan tapioka berpengaruh sangat nyata terhadap kadar lemak kerupuk (tabel 8).

Tabel 8. Hasil uji lanjut BNJ terhadap kadar lemak kerupuk (\%bk)

\begin{tabular}{rc}
\hline Perlakuan & Nilai tengah \\
\hline N7 (60\% jamur tiram dan 40\% tapioka) & $0,75 \mathrm{a}$ \\
N6 (50\% jamur tiram dan 50\% tapioka) & $0,65 \mathrm{~b}$ \\
N5 (40\% jamur tiram dan 60\% tapioka) & $0,62 \mathrm{bc}$ \\
N4 (30\% jamur tiram dan 70\% tapioka) & $0,59 \mathrm{c}$ \\
N3 (20\% jamur tiram dan 80\% tapioka) & $0,58 \mathrm{c}$ \\
N2 (10\% jamur tiram dan 90\% tapioka) & $0,50 \mathrm{~d}$ \\
N1 (100\% tapioka) & $0,43 \mathrm{e}$ \\
\hline
\end{tabular}


BNJ 0,05 = 0,043

Ket : Angka yang diikuti oleh huruf yang berbeda pada kolom yang sama menunjukkan adanya perbedaan nyata $(\mathrm{p}<0.05)$

Berdasarkan Tabel 8, semakin banyak penambahan jamur tiram dalam pembuatan kerupuk meningkatkan kadar lemak kerupuk jamur tiram yang dihasilkan. Hal ini terlihat dari kadar lemak kerupuk hasil formulasi jamur tiram yang mengalami peningkatan seiring dengan makin tinggi jamur tiram yang ditambahkan. Kerupuk tanpa penambahan jamur tiram menghasilkan kadar lemak paling rendah.

Kadar Protein. Hasil analisis sidik ragam menunjukkan bahwa formulasi jamur tiram dan tapioka berpengaruh sangat nyata terhadap kadar protein kerupuk (tabel 9).

Tabel 9. Hasil uji lanjut BNJ terhadap protein kerupuk (\%bk)

\begin{tabular}{lc}
\hline & Perlakuan \\
\hline N7 (60\% jamur tiram dan 40\% tapioka) & Nilai tengah \\
N6 (50\% jamur tiram dan 50\% tapioka) & $4,61 \mathrm{a}$ \\
N5 (40\% jamur tiram dan 60\% tapioka) & $4,23 \mathrm{~b}$ \\
N4 (30\% jamur tiram dan 70\% tapioka) & $3,63 \mathrm{c}$ \\
N3 (20\% jamur tiram dan 80\% tapioka) & $2,87 \mathrm{~d}$ \\
N2 (10\% jamur tiram dan 90\% tapioka) & $2,44 \mathrm{e}$ \\
N1 (100\% tapioka) & $1,79 \mathrm{f}$ \\
\hline
\end{tabular}

BNJ $0,05=0,178$

Ket :Angka yang diikuti oleh huruf yang berbeda pada kolom yang sama menunjukkan adanya perbedaan nyata $(\mathrm{p}<0.05)$

Berdasarkan Tabel 9, terlihat bahwa kadar protein kerupuk pada setiap formulasi berbeda nyata menurut BNJ 5\%. Nilai kadar protein tertinggi terdapat pada formulasi N7 (60\% jamur tiram dan $40 \%$ tapioka), sedangkan nilai kadar protein terendah terdapat pada formulasi N1 (100\% tapioka). Perbedaan kandungan protein pada setiap formulasi kerupuk disebabkan adanya penambahan jamur tiram, sehingga mengakibatkan bertambahnya kadar protein kerupuk. Peningkatan kadar protein terlihat pada kerupuk hasil formulasi dengan penambahan jamur tiram dalam jumlah lebih banyak.

Proses pemanasan akan meningkatkan kompleksitas reaksi antara pati dan protein. Perubahan thermal pada protein menyebabkan terjadinya denaturasi yang dipercepat dengan keberadaan air. Perubahan thermal menyebabkan pati kehilangan kristalinitas, pengembangan granula, dan keluarnya amilosa dari granula meninggalkan amilopektin. Granula pecah dan matriks amilosa membentuk gel. Pada saat protein dan pati bertemu, akan terbentuk matriks protein-pati yang stabil melibatkan ikatan hidrogen, ikatan kovalen, dan rantai ionik (Gaonkar dan McPherson, 2005).

Kadar protein dari ketujuh formulasi kerupuk jamur tiram berada dalam kisaran 1,37\% (\%bk)-4,61\% (\%bk). Sampai saat ini, belum ada penentuan persyaratan mutu untuk produk olahan kerupuk jamur tiram. Berdasarkan stándar mutu (SNI 01-2713-1999), kadar protein kerupuk ikan dan kerupuk udang minimal sebesar 5\%. Hal ini menunjukkan bahwa kadar protein kerupuk jamur tiram pada keenam formulasi jamur tiram belum memenuhi standar mutu SNI untuk jenis kerupuk ikan dan udang.

Kadar Serat Kasar. Hasil analisis sidik ragam menunjukkan bahwa formulasi jamur tiram dan tapioka berpengaruh sangat nyata terhadap kadar serat kasar kerupuk (tabel 10).

Berdasarkan Tabel 10, terlihat bahwa nilai kadar serat kasar kerupuk pada setiap formulasi berbeda nyata menurut BNJ 5\%. Nilai kadar serat kasar tertinggi terdapat pada formulasi N7 (60\% jamur tiram dan 40\% tapioka), sedangkan nilai kadar serat kasar terendah terdapat pada formulasi N1 (100\% tapioka). Kadar serat kasar kerupuk jamur tiram cenderung meningkat dengan semakin banyaknya jumlah jamur tiram yang ditambahkan. Hal ini disebabkan karena kandungan kadar serat kasar jamur tiram sebesar 11,5\% (Suriawiria, 2002) lebih besar daripada kadar serat kasar tapioka sebesar 0,03\% (Wirakartakusumah et al., 1989). 
Astuti, S dkk: Pengaruh Formulasi Jamur Tiram Putih (Pleurotus Oestreatus) dan Tapioka...

Tabel 10. Hasil uji lanjut BNJ terhadap kadar serat kasar kerupuk (\%bk)

\begin{tabular}{lc}
\hline \multicolumn{1}{c}{ Perlakuan } & Nilai tengah \\
\hline N7 (60\% jamur tiram dan 40\% tapioka) & $2,12 \mathrm{a}$ \\
N6 (50\% jamur tiram dan 50\% tapioka) & $1,81 \mathrm{~b}$ \\
N5 (40\% jamur tiram dan 60\% tapioka) & $1,54 \mathrm{c}$ \\
N4 (30\% jamur tiram dan 70\% tapioka) & $0,90 \mathrm{~d}$ \\
N3 (20\% jamur tiram dan 80\% tapioka) & $0,67 \mathrm{e}$ \\
N2 (10\% jamur tiram dan 90\% tapioka) & $0,25 \mathrm{f}$ \\
N1 (100\% tapioka) & $0,11 \mathrm{~g}$ \\
\hline
\end{tabular}

BNJ $0,05=0,116$

Ket : Angka yang diikuti oleh huruf yang berbeda pada kolom yang sama menunjukkan adanya perbedaan nyata $(\mathrm{p}<0.05)$

Kerupuk Jamur Tiram Terbaik. Penentuan kerupuk campuran jamur tiram dan tapioka terbaik didasarkan pada hasil pengamatan terhadap kerupuk yang dihasilkan. Kadar air dan kadar protein kerupuk jamur mengacu pada SNI (01-2713-199) kerupuk ikan, sedangkan pengujian organoleptik dipilih berdasarkan skor terbaik terhadap tekstur, rasa, warna dan aroma. Volume pengembangan kerupuk dipilih berdasarkan pada nilai volume pengembangan yang tinggi.

Tabel 11. Rekapitulasi hasil pengamatan kerupuk hasil formulasi jamur tiram dengan tepung tapioka

\begin{tabular}{llllllll}
\hline \multicolumn{1}{c}{ Hasil pengamatan } & \multicolumn{1}{c}{$\mathrm{N} 1$} & $\mathrm{~N} 2$ & $\mathrm{~N} 3$ & $\mathrm{~N} 4$ & $\mathrm{~N} 5$ & $\mathrm{~N} 6$ & $\mathrm{~N} 7$ \\
\hline Volume pengembangan $(\%)$ & $330,78 \mathrm{abc}^{*}$ & $452,28 \mathrm{a}^{*}$ & $328,53 \mathrm{abc}^{*}$ & $415,54 \mathrm{ab}^{*}$ & $247,95 \mathrm{bc}$ & $205,57 \mathrm{c}$ & $292,61 \mathrm{abc}^{*}$ \\
\hline Tekstur & $3,55 \mathrm{~b}$ & $3,52 \mathrm{~b}$ & $3,47 \mathrm{~b}$ & $3,80 \mathrm{a}^{*}$ & $4,27 \mathrm{a}^{*}$ & $4,15 \mathrm{a}^{*}$ & $4,21 \mathrm{a}^{*}$ \\
\hline Rasa & $2,45 \mathrm{c}$ & $2,47 \mathrm{c}$ & $2,77 \mathrm{~b}$ & $2,77 \mathrm{~b}$ & $2,87 \mathrm{~b}$ & $3,32 \mathrm{a}^{*}$ & $2,87 \mathrm{~b}$ \\
\hline Warna & $4,47 \mathrm{a}^{*}$ & $4,08 \mathrm{ab} *$ & $3,48 \mathrm{bc}$ & $3,18 \mathrm{~cd}$ & $2,88 \mathrm{~cd}$ & $2,53 \mathrm{~d}$ & $2,47 \mathrm{~d}$ \\
\hline Aroma & $2,33 \mathrm{c}$ & $2,53 \mathrm{~b}^{*}$ & $2,68 \mathrm{~b}^{*}$ & $2,70 \mathrm{ab} *$ & $2,78 \mathrm{ab} *$ & $2,85 \mathrm{a}$ & $2,93 \mathrm{a}$ \\
\hline Kadar air $(\% \mathrm{bk})$ & $7,53 \mathrm{a}^{* *}$ & $7,20 \mathrm{~b}^{* *}$ & $6,70 \mathrm{c}^{* *}$ & $6,72 \mathrm{c}^{* *}$ & $6,39 \mathrm{~d}^{* *}$ & $6,31 \mathrm{~d}^{* *}$ & $6,23 \mathrm{~d}^{* *}$ \\
\hline Kadar protein $(\% \mathrm{bk})$ & $1,27 \mathrm{~g}$ & $1,66 \mathrm{f}$ & $2,27 \mathrm{e}$ & $2,68 \mathrm{~d}$ & $3,96 \mathrm{c}$ & $3,97 \mathrm{~b}$ & $4,32 \mathrm{a}$ \\
\hline Jumlah bintang & 2 & $\mathbf{3}$ & 2 & 3 & 2 & 2 & 2 \\
\hline Ketangan $:$ & & & & & & & 2
\end{tabular}

Keterangan :

$\mathrm{N} 1=0 \%$ jamur tiram dan $100 \%$ tapioka

$\mathrm{N} 2=10 \%$ jamur tiram dan $90 \%$ tapioka

$\mathrm{N} 3=20 \%$ jamur tiram dan $80 \%$ tapioka

$\mathrm{N} 4=30 \%$ jamur tiram dan $70 \%$ tapioka

$\mathrm{N} 5=40 \%$ jamur tiram dan $60 \%$ tapioka
N6 $=50 \%$ jamur tiram dan $50 \%$ tapioka

$\mathrm{N} 7=60 \%$ jamur tiram dan $40 \%$ tapioka

* = sesuai statistik tidak berbeda nyata pada taraf $5 \%$

** = sesuai SNI pada kerupuk ikan

Hasil penelitian menunjukkan bahwa formulasi N2 (10\% jamur tiram dan 90\% tapioka) merupakan perlakuan terbaik. Kerupuk ini memiliki volume pengembangan tertinggi sebesar $452,28 \%$, tekstur agak renyah, rasa tidak khas jamur, warna putih kekuningan, aroma agak khas jamur, kadar air 7,20\% (\%bk), kadar abu 1,03\% (\%bk), kadar lemak 0,46\% (\%bk), kadar protein 1,66\% (\%bk), dan kadar serat kasar 0,24\% (\%bk). Namun kadar protein yang dihasilkan belum memenuhi standar mutu kerupuk (SNI01-2713-1999).

\section{KESIMPULAN}

Kesimpulan yang diperoleh dalam penelitian ini adalah formulasi jamur tiram dan tapioka berpengaruh sangat nyata terhadap volume pengembangan kerupuk, tekstur, rasa, warna, aroma, kadar air, kadar abu, kadar lemak, kadar protein, dan kadar serat kasar kerupuk jamur tiram ; Formulasi N2 (10\% 
Jurnal Penelitian Pertanian Terapan

jamur tiram dan $90 \%$ tapioka) merupakan formulasi kerupuk jamur tiram terbaik dengan volume pengembangan tertinggi sebesar 452,28\%, tekstur agak renyah (skor 3,45), rasa tidak khas jamur (skor 2,47), warna putih kekuningan (skor 4,08), aroma agak khas jamur (skor 2,53), kadar air 7,20\% (\%bk), kadar abu $1,03 \%$ (\%bk), kadar lemak 0,46\% (\%bk), kadar protein 1,66\% (\%bk), dan kadar serat kasar 0,24\% (\%bk). Namun kadar protein yang dihasilkan belum memenuhi standar mutu kerupuk (SNI 01-2713-1999).

\section{DAFTAR PUSTAKA}

AOAC. 1995. Official Methods of the Association of Official Analytical Chemists. North Ninetenth Street Suite 210. Virginia.

Astawan, M. dan Christina. 1998. Kajian Mutu Kerupuk Kemplang dari Ikan Gabus dan Ikan Tenggiri. Ilmu dan Teknologi Pangan 3(2):11-20.

Bernas, E., G. Jaworska, and Z. Lisiewska. 2006. Edible Mushrooms as a Source of Valuable Nutritive Constituents. Acta Science Pol Technology Aliment 5(1):5-20.

Cahyana, Y.A., Muchrodji, dan M. Bakrun. 1999. Jamur Tiram Pembibitan Pembudidayaan Analisis Usaha. Penebar Swadaya, Jakarta.

Chinachotti, P., M.P. Steinberg, and R. Villota. 1990. A Model for Quantitating Energy and Degree of Starch Gelatinization Based on Water, Sugar and Salt Contents. Journal of Food Science 55:543-546.

Gaonkar, A. G. and A. McPherson. 2005. Ingredient Interactions Effects on Food Quality. Second Edition.CRC Press. Boca Raton, Florida.

Haryadi. 1994. Physical Characteristics and Acceptability of the Kerupuk Crackers from Different Starches. Indonesian Food and Nutrition Product. 1(1):23-26.

Kusnandar, F. 2010. Kimia Pangan Komponen Makro. PT Dian Rakyat. Jakarta.

Lu, S., C-Y. Chen, and C.Y. Lii. 1996. Gel-cromatography Fractionation and Thermal Characterization of Rice Starch Affected by Hydrothermal Treatment. Cereal Chemistry 73(1):5-11.

Martawijaya, E.I. dan M.Y. Nurjayadi. 2010. Bisnis Jamur Tiram di Rumah Sendiri. IPB Press. Bogor.

Muchtadi, T.R., P. Hariadi dan A.B. Aliya. 1988. Teknologi Pemasakan Ekstruksi. Institut Pertanian Bogor. Bogor.

Muryati. 1996. Pengaruh Perbandingan Bahan terhadap Daya Kembang Kerupuk Jamur. Bulletin Penelitian Pengembangan Industri (20):16-19.

Patel, Y., R. Naraian, and V.K. Singh. 2012. Medicinal Properties of Pleurotus Species(Oyster Mushroom) : a Review. World Journal of Fungal and Plant Biology 3(1):1-12.

Rahardjo, A.P. dan Haryadi. 1997. Beberapa Karakteristik Kerupuk Ikan yang Dibuat dengan Variasi Rasio Ikan Nila/Tapioka dan Lama Perebusan Adonan. Agritech. 17(2):23-26.

Ridwan, I. N., B. Rinaldi, I. Suharto dan A. Rasma. 1994. Pengaruh Suplementasi Tepung Kedelai dan Natrium Tripolifosfat terhadap Sifat Fisiko-kimia Kerupuk Pangsit Berprotein. Dinamika Penelitian. BIPA 5(9):46-54.

Suriawiria, H.U. 2002. Budidaya Jamur Tiram. Kanisius. Yogyakarta. 54 hlm. 
Astuti, S dkk : Pengaruh Formulasi Jamur Tiram Putih (Pleurotus Oestreatus) dan Tapioka...

Standar Nasional Indonesia. 1999. Kerupuk Ikan SNI 01-2713-1999. Badan Standardisasi Nasional. Jakarta.

Tester, R.F. and W.R. Morrison. 1990. Swelling and Gelatinization of Cereal Starches I: Effect of Amylopection, Amylose, and Lipids. Cereal Chemistry 74:750-757.

Winarno, F.G. 1997. Pangan, Gizi, Teknologi dan Konsumen. PT Gramedia Pustaka Utama. Jakarta.

Winarno, F.G. 2004. Kimia Pangan dan Gizi. Gramedia Pustaka Utama. Jakarta.

Wirakartakusumah, M.A., D. Hermanianto, dan N. Andarwulan. 1989. Prinsip Teknik Pangan. Departemen Pendidikan dan Kebudayaan Direktorat Jenderal Pendidikan Tinggi Pusat Antar Universitas Pangan dan Gizi Institut Pertanian Bogor. Bogor.

Zulviani, R. 2000. Pengaruh Berbagai Tingkat Suhu Penggorengan Terhadap Pola Pengembangan Kerupuk Sagu Goreng. (Skripsi). Institut Pertanian Bogor. Bogor. 